\title{
REPRESENTASI KONSEP KETUHANAN: ANALOGI CERITA DALAM NOVEL SEMUA IKAN DI LANGIT KARYA ZIGGY Z.
}

\author{
Ila Rohmatin Shofa \\ Prodi Pendidikan Bahasa dan Sastra Indonesia, Fakultas Keguruan dan Ilmu Pendidkan, \\ Universitas Muhammadyah Malang \\ Ilarohmatin99@gmail.com
}

\begin{abstract}
ABSTRAK
Novel Semua Ikan di Langit menceritakan kisah berbagai perjalanan sebuah Bus Damri dan berbagai macam penumpangnya. Salah satu karakter dalam novel ini yaitu Beliau, Beliau lah yang memimpin perjalanan sebuah Bus dalam kota dan ikan julung-julung di luar Angkasa. Tokoh Beliau bisa jadi adalah metafora dari Tuhan yang mengenalkan dunia dan seisinya kepada sebuah bus. Permasalahan dalam penelitian ini yaitu, bagaimana konsep Ketuhanan dan makna simbolik Ketuhanan yang disajikan dalam novel Semua Ikan di Langit. Tujuan dari penelitian ini yaitu, mendeskripsikan konsep Ketuhanan dan makna simbolik Ketuhanan dalam novel Semua Ikan di Langit. Metode analisis yang digunakan dalam penelitian ini adalah metode deskriptif kualitatif dengan pendekatan Semiotika. Hasil penelitaian akan menunjukkan konsep Ketuhanan yang di representasikan melalui cerita-cerita dari berbagai perjalanan Beliau,ikan julung-julung. Bus damri dan yang lainnya. Dari perjalanan Beliau dan rombongan dapat ditemukan beberapa sifat Beliau yang mirip bahkan sama dengan Tuhan. Beberapa sifat Tuhan yang juga dimiliki Tokoh Beliau yaitu, Maha Mendengar, Maha Kuasa, Maha Mengetahui dan juga Zat yang abadi.
\end{abstract}

Kata kunci: Ketuhanan, Analogi, Representasi

\section{PENDAHULUAN}

Ketuhanan merupakan segala sesuatu yang berhubungan dengan Tuhan atau sifat akan adanya Tuhan. Menurut Socrates, seorang ahli Filsafat terdapat dua jalan mengenai sistem pengetahuan manusia tentang Tuhan. Pertama, berdasar pada bukti-bukti alam. Kedua, dengan alasan-alasan sejarah.

Manusia, sejak pertama kali mulai berpikir, sudah mengenal adanya suatu kekuatankekuatan yang mengatasi manusia, sesuatu yang dianggap Maha Kuasa, sesuatu yang mampu mendatangkan keajaiban, kebaikan, keburukan bahkan dapat mengabulkan doa dan keinginan (Baharudin, 2014: 35-36) 


\section{Ila Rohmatin Shofa : Representasi Konsep Ketuhanan: Analogi Cerita dalam Novel semua Ikan di Lagit Karya Ziggy Z \\ Website : https://jurnal.umj.ac.id/index.php/penaliterasiEmail : penaliterasi@umj.ac.id}

Manusia yang merupakan pribadi insani dan Tuhan yang merupakan pribadi Illahi yang saling berhubungan. Manusia mengenal dan mengetahui Tuhan tidak secara langsung bertemu, melainkan melalui alam yang tidak sempurna. Cara manusia mengenal sikap Tuhan pun tidak secara langsung, jadi tidak begitu akurat karena berlangsung secara tidak sempurna. Manusia mengetahui sifat-sifat Tuhan terkadang dengan cara yang tidak terduga, dengan apa yang terjadi di dunia akan menyadarkan manusia tentang Tuhan dan ciptaannya.

Pandangan Al-kindi tentang Islam sangat bertentangan dengan pendapat Aristoteles, Plato, dan Plotinus. Al-kindi berpandangan bahwa Ketuhanan sesuai dengan ajaran Islam. Dalam pandangannya, Allah adalah wujud sesungguhnya, bukan berasal dari tiada dan kemudian ada. Ia tidak ada, Ia selalu ada dan akan ada selamanya. Allah merupakan wujud yang sempurna dan tidak ada wujud lain yang mendahului. Wujudnya tidak dapat berakhir seperti wujud lain yang disebabkan wujudnya. Allah adalah Tuhan yang Maha Esa yang tidak dapat dibagi dan tidak ada Dzat lain yang dapat menyamainya dalam aspek apapun. Ia juga tidak melahirkan pula melahirkan (Zar, 2004:50).

Jalan cerita pada novel Semua Ikan di Langit merupakan kisah yang jarang diangkat oleh penulis lain. Ketuhanan adalah tema utama pada Novel Semua Ikan di Langit. Melalui Beliau, tanda-tanda atau segala sesuatu yang berhubungan dengan Tuhan disampaikan. Novel ini dikaji menggunakan pendekatan Semiotika, Semiotika merupakan ilmu yang mengkaji suatu hal yang berhungan denagn tanda. Menurut Charles Sanders Peirce seorang ahli filsuf dari Amerika mengatakan bahwa kehidupan manusia dicirikan oleh pencampuran tanda dan cara penggunaannya dalam sebuah aktivitas yang bersifat representatif atau mewakili (Danesi dalam Patriansyah, 2014: 242).

Kehidupan manusia dipenuhi oleh tanda, dengan perantaraan tanda-tanda proses kehidupan menjadi lebih efisien, dengan perantaraan tanda-tanda manusia dapat berkomunikasi dengan sesamanya, sekaligus pemahaman yang lebih baik terhadap dunia, dengan demikian manusia adalah Homo Semioticus. Konsep Ketuhanan merupakan seluruh elemen yang membuat seseorang memiliki pandangan tentang adanya Tuhan dan segala sesuatu yang berhubungan dengan Tuhan. Konsep Ketuhanan yang dimaksud dalam penelitian ini yaitu representasi dari cerita-cerita tentang tokoh Beliau yang menggambarkan tentang hal-hal yang berhubungan dengan Tuhan. Segala sesuatu yang terjadi di dunia adalah kuasa Tuhan.

\section{Novel Semua Ikan di Langit} merupakan novel yang menceritakan perjalanan sebuah bus yang dipimpin oleh Beliau. Keunikan pada novel Semua Ikan di Langit terletak pada tokoh-tokoh yang tersaji, mulai dari Beliau yang terbang, Bus damri berwarna merah dalam kota hingga ikan julung-julung yang dapat berubah sewaktu-waktu sesuai dengan suasana hati Beliau. Cerita yang disajikan pada novel terhitung berbeda dengan novel-novel pada umumnya. Tokoh manuisa bukan karakter yang dominan diceritakan pada novel.

Penelitian ini dikaji menggunakan teori Semiotika. Semiotik berkaitan dengan tanda, Lechte berkata bahwa Semiotik merupakan teori tentang tanda dan 


\section{Ila Rohmatin Shofa : Representasi Konsep Ketuhanan: Analogi Cerita dalam Novel semua Ikan di Lagit Karya Ziggy Z \\ Website : https://jurnal.umj.ac.id/index.php/penaliterasiEmail : penaliterasi@umj.ac.id}

penandaan. Lebih jelasnya lagi Semiotik merupakan disiplin ilmu yang mengkaji semua bentuk komunikasi yang terdiri dari tanda-tanda (sign) dan berdasar pada sistem tanda (sign system) (Sobur, 2003: 16). Semiotik sendiri merupakan jalan keluar untuk ketidakpahaman makna secara strukturalisme mengenai unsur-unsur bahasa dalam sebuah karya sastra. Dengan adanya ilmu Semiotik atau ilmu tanda ini sekaligus sebagai pemecah sebuah makna yang hanya bersembunyi dibalik makna aslinya.

Permasalahan yang dikaji pada penelitian ini yaitu, bagaimanakah konsep Ketuhanan disajikan melalui tanda-tanda simbolik dan analogi cerita dalam novel Semua Ikan di Langit. Berkaitan dengan permasalahan tersebut, tujuan dari peneltian ini yaitu, mendeskripsikan konsep Ketuhanan dan simbolik Ketuhanan dalam novel Semua Ikan di Langit.

\section{METODE PENELITIAN}

Metode yang digunakan pada penelitian ini merupakan metode deskriptif kualitatif dengan pendekatan Semiotika. Sasaran utama pada penelitian ini adalah konsep Ketuhanan yang dianalogikan dengan cerita perjalanan Beliau dan Bus Damri serta makna simbolik Ketuhanan dalam novel Semua Ikan di Langit. Data pada penelitian merupakan data deskriptif yang terdapat pada novel Semua Ikan di Langit yang berupa ungkapan pada setiap paragraf yang berisi tentang konsep Ketuhanan yang dianalogikan dengan cerita-cerita dari tokoh Beliau. Adapun sumber data penelitian ini menggunakan sumber data primer dan skunder. Sumber data primer pada penelitian ini berupa novel Semua Ikan di Langit karya Ziggy Z. dengan tebal novel 261 halaman dan terbit pada tahun 2016. Data sekunder pada penelitian ini berupa buku-buku dan jurnal yang berisi informasi tentang konsep Ketuhanan dan makna simbolik dalam kajian Semiotika. Teknik pengumpulan data yang digunakan yaitu dengan cara menguraikan atau mendeskripsikan faktafakta. Dalam ilmu sosial sumber data yang digunakan adalah masyarakat, data penelitiannya yatu tindakan-tindakan, sedangkan dalam ilmu sastra sumber data berasal dari karya dan naskah, data penelitian sebagai data formal yatiu berupa kata-kata, kalimat dan wacana. Penggunaan metode deskriptif kualitatif bertujuan untuk memperoleh data yang bersifat apa adanya dan hasilnya lebih menekankan pada makna.

\section{HASIL DAN PEMBAHASAN}

\section{Analogi Cerita-cerita Beliau sebagai Tuhan}

Konsep Ketuhanan yang direperensentasikan dengan cerita-cerita perjalanan Beliau pada novel menggambarkan tanda atau bahkan mengingatkan manusia akan adanya Tuhan. Konsep ini muncul dilandasi atas kepercayaan-kepercayaan manusia akan hadirnya Tuhan dalam suatu kehidupan. Perbuatan apapun yang dilakukan di dunia akan berhubungan dengan Tuhan. Pada novel Semua Ikan di Langit Tuhan dimetaforakan dengan tokoh Beliau. Beliau, wujudnya kecil, tidak menapak, tidak bernafas, dan tidak bicara. Ciri fisik tersebut memang tidak dapat dikaitkan langsung dengan wujud Tuhan, akan tetapi sifat-sifat Beliau lah yang difokuskan pada penlitian ini. Beliau yang memimpin perjalanan bus damri dalam kota dan ikan julung julung di luar Angkasa. Beliau 
Ila Rohmatin Shofa : Representasi Konsep Ketuhanan: Analogi Cerita dalam Novel semua Ikan di Lagit Karya Ziggy $Z$

Website : https://jurnal.umj.ac.id/index.php/penaliterasiEmail : penaliterasi@umj.ac.id

mengenalkan dunia dan seluruh isinya pada sebuah bus. Sifat-sifat keilahian yang dimiliki Beliau disuguhkan dalam novel ini hingga berkali-kali. Beliau diceritakan memiliki kemampuan ajaib.

“Akan tetapi, Beliau tetap
tidak bicara, tidak menapak.
Namun, perasaan yang
begitu kuat memberi tahu
saya bahwa, bahkan
meskipun Beliau berbuat
demikian, bukan berarti
Beliau tidak mau dipahami.
Mungkin ini adalah ujian:
Apakah saya akan terus
mencoba memahami dan
memperhatikannya,
meskipun Beliau tidak
berkomunikasi langsung
dengan saya?”
(Zezsyazeoviennazabrizkie,

2016: 33)

Bus damri yang merupakan bus dalam kota, dapat membaca pikiran siapapun jika menapakkan kaki ke lantai bus. Semua yang ada dipikiran penumpangnya akan terbaca oleh bus damri. Berbeda dengan Beliau, bus tidak tau apa yang sedang dalam pikiran Beliau. Beliau tidak menapakkan kaki ke lantai dan tidak juga bicara. Namun, bus berpikir bahwa meski demikian, Beliau bukan tidak ingin dipahami tapi hal itu merupakan suatu ujian. Apakah bus akan terus mencoba memahami dan memperhatikan meskipun Beliau tidak dapat berkomunikasi dengan bus. Analogi cerita tersebut yaitu, manusia, meskipun tidak mendengar apa yang Tuhan katakan dan apa yang sedang dipikirkan Tuhan tetap harus memahami dan memperhatikan. Manusia hanya dapat berkomunikasi dengan Tuhan melalui doa, dan Tuhan akan menjawab dengan hal-hal yang tak pernah diduga oleh manusia.

Tuhan adalah Dzat yang Maha Berkehendak. Tuhan dapat menentukan segala seuatu, dengan berkata "Jadilah" maka apapun dapat terjadi dan tidak satupun dapat mencegahnya.

"Sejauh ini, saya saya sudah
melihat apa yang bisa Beliau
lakukan dengan peralatan
jahit yang disimpan di
kantong-kantong mantelnya.
Seperti peralatan jahit pada
umumnya, yang bisa Beliau
lakukan dengan barang-
barang itu adalah menjahit.
Mulai dari yang paling
umum, sampai yang paling
aneh: boneka untuk
dijatuhkan ke pelukan anak-
anak, pakaian untuk
menghangatkan orang-orang
yang tersesat pada malam
hari, dan hati yang patah.
Semua yang Beliau lakukan
dengan jarum dan benangnya
adalah hal yang membuat
orang lain bahagia, hal yang
menyembuhkan rasa sakit."
(Zezsyazeoviennazabrizkie,
2016: 55)

Beliau adalah sosok anak kecil yang selalu membawa peralatan jahit di kantong mantelnya. Dari peralatan jahit tersebut, Beliau dapat membuat apapun yang diinginkan. Mulai dari boneka hingga pakaian. dalam novel ini, Beliau diceritakan sebagai seseorang yang dapat membuat semua orang bahagia bahkan menyembuhkan rasa sakit dengan apapun yang dilakukan dengan peralatan jahitnya. 


\section{Ila Rohmatin Shofa : Representasi Konsep Ketuhanan: Analogi Cerita dalam Novel}

semua Ikan di Lagit Karya Ziggy $Z$

Website : https://jurnal.umj.ac.id/index.php/penaliterasiEmail : penaliterasi@umj.ac.id

Analogi dari cerita tersebut yaitu, Tuhan merupakan Dzat pencipta segalanya yang ada di dunia. Tuhan menciptakan manusia juga sekaligus membuat sekenario hidupnya. Tuhan juga merupakan Dzat yang bisa membantu manusia keluar dari jalan yang tidak semestinya. Dengan manusia memohon dan berdoa, Tuhan akan mendengar dan akan menolong setiap hambanya.

Beliau adalah sesorang yang dapat melakukan apapun sesuai dengan suasana hatinya. Ketika Beliau marah, Beliau bahagia, Beliau sedih dan lain sebagainya. Manusia tidak pernah tahu apa yang akan terjadi.

"Beliau, menyadari tawaran saya, ,menghentikan gerakan para ikan. Amarahnya berkurang sedikit. Matanya memandangi lantai saya, seperti mengatakan bahwa, tidak, saya tak usah mengotori moncong saya dengan urusan yang membuat Beliau marah.

Kalau Beliau yang diusik, berarti Beliau yang akan mengurusnya. Tak usah repot-repot, Beliau bisa mengatasinya sendiri." (Zezsyazeoviennazabrizkie, 2016: 57)

Pada novel ini Beliau diceritakan sebagai seseorang yang maha kuasa, Beliau dapat melakukan apapun yang Beliau mau. Hujan menandakan bahwa Beliau sedih, bayak bintang di langit menandakan bahawa Beliau sedang bahagia, begitupun ketikan Beliau sedang marah, apapun bisa Beliau lakukan. Bus damri tidak usah mengotori dirinya utuk hal-hal yang mengusik Beliau. Beliau dapat mengatasi sendiri. Data tersebut sangat sesuai jika dikaitkan dengan sifat Tuhan yang Berdiri atas sendiri-Nya. Tuhan adalah Dzat yang maha berkehendak. Tuhan tidak bergantung pada bantuan apapun dan siapapun. Tuhan Maha Kuasa, maha segalanya. Barang siapa yang mengusik kedamaian, Tuhan tidak segan-segan memberikan pelajaran pada siapapun yang berbuat. Begitupun ketika Tuhan merasa bahagia, Tuhan akan memberikan hal yang tidak akan didugaduga oleh manusia. Tuhan akan melakukannya semua sendiri tanpa bantuan tangan siapapun.

"Beliau memang tidak secara
langsung menghajar orang
yang kurang ajar, tapi Beliau
bisa menjahit mata mereka,
atau melakukan sesuatu yang
membuat mereka mederita
dalam jangka waktu panjang
dengan keajaibannya."
(Zezsyazeoviennazabrizkie,
2016: 107)

Beliau bukan sesorang yang instan, apapun akan Beliau lakukan saat itu juga. Tidak selalu seperti itu, ada kalanya Beliau menarik ulur. Seperti ketika Beliau melihat seorang lelaki yang menghajar kakek tua. Beliau marah, tapi Beliau tidak langsung memberi pelajaran. Beliau akan menghukum perlahan dan membiarkan lelaki itu menderita dalam jangka waktu panjang. Begitu pula Tuhan, Tuhan tidak akan mebiarkan siapapun yang berbuat tidak sopan pada orang yang lebih tua. Tuhan tidak menyukai bahkan membenci orang-orang yang berbuat demikian. Tuhan akan memberikan pelajaran pada siapapun itu, baik secara langsung ataupun perlahan. 
Ila Rohmatin Shofa : Representasi Konsep Ketuhanan: Analogi Cerita dalam Novel semua Ikan di Lagit Karya Ziggy $Z$

Website : https://jurnal.umj.ac.id/index.php/penaliterasiEmail : penaliterasi@umj.ac.id

"Ketika Beliau mendengar,

Beliau bukan hanya

mendengar. ketika Beliau

mendegar, Beliau

mendengar"

(Zezsyazeoviennazabrizkie,

2106: 80)

Tuhan adalah Dzat yang Maha Mendengar baik yang diucapkan maupun yang disimpan dalam hati. Apapun itu, Tuhan mengetahui. Begitupun Beliau, bukan hanya dapat melakukan apapun sesuai kehendaknya, Beliau juga dapat mengerti apa yang dipikirkan oleh setiap makhuk hidup.

\section{"Saya tidak bisa melakukan apa-apa. Tapi Beliau, untungya, mendengar. Seperti biasa, Beliau mendengar. Beliau mendengar semua kata-kata yang tidak diucapkan. Beliau memikirkannya, mempertimbangkannya, lalu memutuskan sesuatu." (Zezsyazeoviennazabrizkie,} 2016: 115)

Beliau tidak hanya sekedar mendengar lalu melupakan apa yang dikatakan ataupun dipikirkan manusia dan makhluk hidup di dunia bahkan di Angkasa. Beliau benar-benar mendengar, Beliau menyimak. Ketika bus ingin kembali ke Bumi, bus tidak mengatakannya tapi hanya sebuah keinginan hatinya. Beliau mendengar perasaan hati bus, lalu dalam sekejap Beliau membawa turun bus ke Bumi. Dari cerita tersebut terdapat analogi bahwa, Tuhan adalah Dzat yang Maha Mendengar. Bukan sekedar mendengar, Tuhan memahami lalu mengiyakan apa yang dikatakan manusia. Manuisa atau makhluk hidup kadang mengatakannya langsung dengan keras, kadang melalui doa ketika sembahyang, kadang hanya bisikan dalam hati, dan Tuhan mendengarkan semuanya, dengan cara apapun. Kemudian, Tuhan memikirkan, mempertimbangkan, lalu memutuskan sesuatu dan megabulkan satu persatu.

Beliau dapat melakuakan apapun dengan tangan kecilnya. Melakukan suatu hal yang tidak pernah terbayangkan sebelumnya, melakukan hal-hal yang tidak pernah bisa dilakukan manusia, apalagi bus damri yang hanya bus tua yang sudah tidak dipakai lagi oleh sopir dan kondektur.

"Semua hal di dunia; semua

boneka, semua kecoa, semua manusia, dibuat oleh tangan

Beliau. Dengan tangan kecilnya yang menumpahkan usaha, rasa dan sedikit eksperimen pada karyakaryanya. Semua dirangkai sendiri satu persatu, dengan hati-hati, dengan cobacoba."

(Zezsyazeoviennazabrizkie, 2016: 123)

Sifat-sifat Illahiah dari Beliau semakin terlihat ketika bus damri mengatakan bahwa semua hal yang ada di dunia merupakan hasil karya dari tangan Beliau. Mulai dari makhluk hidup sampai benda mati. Beliau merupakan analogi Tuhan bukan lagi asumsi belaka. Tuhan merupakan Dzat pencipta alam semesta dan isinya. Tapi bedanya, Tuhan tidak menciptakan benda mati, manusia yang membuat benda mati, tapi tetap atas kehendak Tuhan. 
Ila Rohmatin Shofa : Representasi Konsep Ketuhanan: Analogi Cerita dalam Novel semua Ikan di Lagit Karya Ziggy $Z$

Website : https://jurnal.umj.ac.id/index.php/penaliterasiEmail : penaliterasi@umj.ac.id

Asumsi bahwa Beliau adalah Tuhan lebih diperkuat lagi oleh pernyataan sebuah pohon besar di luar angkas. Besarnya lebih besar dari Bumi dan Matahari. Ketika Beliau dan Ikan julung-julung juga bus damri pergi ke Angkasa, bus damri menemukan sebuah pohon raksasa yang ukurannya berkali kali lipat ukuran badannya dan berusia sudah berabad-abad. Di setiap daun pohon raksasa terdapat telurtelur, ratusan telur, bahkan ribuan atau jutaan.

\begin{abstract}
"Hm! Hm! Saya beternak jiwa"

"Di dalam telur-telur itu adalah jiwa manusia, hewan, tumbuhan, dan berbagai jenis lainnya. Di bawah dedaunan saya, mereka mendengarkan cerita tentang kehidupan, kematian, tentang Beliau, tentang segalanya, kalau mereka sudah cukup banyak mendengar, Beliau akan menjahitkan cerita hidup mereka dari saat mereka keluar dari ibu mereka, sampai mereka kembali lagi kepada Beliau hm, hm"
\end{abstract} (Zezsyazeoviennazabrizkie, 2016: 130)

"Anda berpergian dengan seseorang yang bisa menimbulkan siang dan malam tanpa membutuhkan matahari, hm. Mengubah cerita orang adalah perkara muda"

Kutipan di atas jelas mengungkapkan bahwa Beliau adalah Tuhan. Beliau memberi kehidupan pada jiwa-jiwa manusia beserta cerita hidup yang akan dibawa ke dunia. Beliau juga diceritkan dapat mengganti jalan cerita yang sudah dibuat dengan mudah dengan peralatan jahitnya. Dalam kutipan di atas pun disebutkan bahwa jiwa-jiwa manusia yang diberi kehidupan tersebut kelak juga akan kembali lagi kepada Beliau. Selain itu, Beliau juga dapat menimbulkan siang dan malam. Dari kutipan tersebut Beliau adalah Tuhan jelas kebenarannya. Tuhan menciptakan manusia dengan segala cerita hidupnya, Tuhan juga dapat merubah cerita tersebut sesuai dengan tingkah laku manusia di dunia dan ketika saatnya telah tiba, maka manusia tersebut akan kembali lagi kepada Tuhan. Karena pada dasarnya, hakikat manusia adalah terbuat dari tanah dan akan kembali ke tanah. Seluruh umat manusia di dunia juga mengetahui, bahwa Tuhan lah yang menciptkan siang dan malam, menciptakan bulan dan matahari.

Analisis makna simbolik pada novel Semua Ikan di Langit dengan kajian Semiotika

Dalam Bahasa Indonesia, pada umumnya simbol disamakan dengan lambang. Akan tetapi dalam sastra, sistem simbol yang terpenting adalah bahasa. ( Leach dalam Ratna, 2004: 115) mengatakan bahwa suatu gejala disebut simbol atau tanda tergantung dari penggunaannya. Tanda bahasa dalam sastra begitu banyak. Simbol juga dapat dianalisis melalui suku kata, kalimat, paragraf dan lain-lain.

Simbol juga merupakan suatu tanda, akan tetapi tidak semua tanda berupa simbol. Simbol memiliki arti ekspresi yang mengekspresikan banyak makna. Ekspresi simbolik merupakan kepenuhan bahasa. Ambiguitas simbol merupakan suatu kekuatan dalam sebuah karya sastra dan 
Ila Rohmatin Shofa : Representasi Konsep Ketuhanan: Analogi Cerita dalam Novel semua Ikan di Lagit Karya Ziggy $Z$

Website : https://jurnal.umj.ac.id/index.php/penaliterasiEmail : penaliterasi@umj.ac.id

kekayaan maknanya terletak pada ambiguitas tersebut.

\section{Simbol "Kebahagiaan"}

Beliau adalah seseorang yang dapat merasakan kebahagiaan. Beliau dengan tegas mengekspresikan dirinya ketika sedang bahagia. "ikan-ikan bergerak naik turun dan berserdawa keras" dapat diartikan bahwa ketika Beliau merasa bahagia, ikanikan berserdawa dan mengeluarkan titiktitik cahaya yang menyebar ditengah kegelapan. Titik-titik cahaya tersebut merupakan bakal bintang. Dapat diartikan bahwa, ketika bintang-bintang di langit begitu kemerlap dan banyak maka pada saat itu Tuhan sedang bahagia.

"Karena Beliau tidak pernah mengubah air mukanya, saya tidak tahu bagaimana wajah Beliau ketika senang. Saat ini pun, wajah Beliau masih seperti itu saja: Matanya membelalak lebar tanpa berkedip, bibirnya terkatup rapat, hidungnya tak mengembuskan nafas. Tapi, ikan-ikan mulai bergerak naik turun sambil berenang berkeliling, membentuk orbit di atas kepala Beliau, dan mulai berserdawa keras." (Zezsyazeoviennazabrizkie, 2016: 36)

Tuhan merupakan Dzat yang Maha Kuasa. Artinya Tuhan Maha Kuasa atas segala sesuatu. Kekuasaan Tuhan yang begitu luas tersebut dapat menghasilkan hal-hal yang di luar dugaan manusia. Apapun dapat terjadi atas kekuasaan Tuhan. pada novel Semua Ikan di Langit diceritakan bahwa Beliau sedih ketika melihat ada peperangan terjadi di dunia. Ketika Beliau bahagia para ikan akan berserdawa dan mengeluarkan titik-titik kecil yang bercahaya, akan tetapi berbeda ketika Beliau merasa sedih. Ikan julungjulung akan berubah meleleh menjadi tetesan perak dan menghujam tanah. Itu adalah hujan ikan julung-julung. Hujan, menandakan kesedihan Beliau, menandakan bahwa Beliau sedang menangis untuk peperangan untuk hal-hal lain yang membuat Beliau sedih.

"Saya hanya bisa melihat Beliau dari belakang, tapi saya menangkap pemandangan bahunya yang gemetar hebat. Begitu hebat, sampai para ikan mulai berterbangan menjauh, menukik kearah langit, dan secara tiba-tiba, meleleh yang menjadi tetesan perak yang menghunjam tanah." (Zezsyazeoviennazabrizkie, 2016: 48)

"Saya ingat betapa banyaknya laki-laki manusia yang mengeluh bahwa semakin lama, semakin sulit melihat bintang di langit. Mungkinkah kebahagiaan Beliau mulai kalah dimakan kekecewaan orang mati? Apa yang terjadi kalau Beliau berhenti merasa bahagia sama sekali? Apakah seluruh dunia, siang dan malam, akan dipenuhi kegelapan?"

Simbol "Kesedihan". 


\section{Ila Rohmatin Shofa : Representasi Konsep Ketuhanan: Analogi Cerita dalam Novel}

semua Ikan di Lagit Karya Ziggy $Z$

Website : https://jurnal.umj.ac.id/index.php/penaliterasiEmail : penaliterasi@umj.ac.id

(Zezsyazeoviennazabrizkie,

2016: 76)

Ketika Beliau sedih, tidak ada bintang di langit. Langit hanya akan gelap karena mendung, hujan akan turun.

\section{Simbol "Kemarahan"}

Selain bahagia dan sedih, Beliau juga bisa marah. Kemarahan Beliau disebabkan oleh banyak hal, salah satunya adalah Beliau tidak suka dengan sikap anak muda yang tidak memiliki sopan santun terhadap orang yang lebih tua. Ikan julung-julung adalah gambaran perasaan Beliau. Ketika Beliau bahagia, Beliau sedih dan Beliau marah ikan julung-julung yang akan bereaksi menggambarkna perasaan Beliau. Ketka Beliau marah ikan julung-julung akan megamuk dan berubah ganas dan akan menyerang siapapun

"setelah para ikan tenang, Beliau meluncur keluar dan menghampiri si lelaki muda. Lelaki itu tampak terkejut dengan kedatanagn Beliau dan ikan-ikannya. Dan, berada begitu dekat dengan lelaki yang telah berbuat kejam, membuat ikan-ikan kecil itu kembali mengamuk. Mereka memelesat dan menusuk-nusuk si lelaki dengan ganas." (Zezsyazeoviennazabrizkie, 2016: 57)

Ketiga simbol di atas merupakan penanda suasana hati atau perasaan Beliau. Ketika Beliau bahagia, langit akan dipenuhi dengan bintang, ketika Beliau sedih, langit akan mendung dan hujan, tidak ada cahya yang menghiasi langit, dan ketika terjadi bencana di dunia, maka hal tersebut adalah penanda bahwa Tuhan sedang marah.

agian hasil menyajikan hasil penelitian yang memuat data (dalam bentuk ringkas), analisis data dan interpretasi terhadap hasil. Hasil penelitian dapat dilengkapi dengan tabel dan grafik (gambar), dan/atau bagan. Pada bagian ini haruslah menjawab masalah atau hipotesis penelitian yang telah dirumuskan sebelumnya.

Bagian pembahasan menyajikan hasil nterpretasi hasil penelitian secara logis, serta mengaitkan dengan sumber rujukan yang relevan. Gunakan drop cap dalam penulisan awal pada bagian ini.

[Times New Roman, ukuran 12, spasi 1,15]

\section{KESIMPULAN}

Dalam novel Semua Ikan di Langit ditemukan konsep Ketuhanan yang disajikan melalui representasi tokoh Beliau dan analogi cerita perjalanan Beliau bersama bus damri dan ikan julung-julung. Peneliti mencoba mengkategorikan sifatsifat Beliau yaitu melalui analogi cerita dan makna simbolik pada novel. Dari analogi cerita dan makna simbolik ditemukan sifatsifat Tuhan yang sesuai dengan Representasi tokoh Beliau pada Novel Semua Ikan di Langit.

Selain dari analogi cerita perjalanan Beliau, beberpa hal yang mendukung Representasi Beliau sebagai Tuhan yaitu tokoh-tokoh di setiap cerita. Pertama, tokoh Nad kecoa betina yang berasal dari Rusia. Tokoh Nad diceritakan tidak percaya dengan keajaiban-keajaban yang dilakukan oleh Beliau dan akhirnya dimusnahkan oleh Beliau di depan Bus Damri. Kedua, pohonpohon raksasa di laur Angkasa. Pohon raksasa di luar Angkasa merupakan saksi ketika Beliau membuat boneka kemudian 
Ila Rohmatin Shofa : Representasi Konsep Ketuhanan: Analogi Cerita dalam Novel semua Ikan di Lagit Karya Ziggy $Z$

Website : https://jurnal.umj.ac.id/index.php/penaliterasiEmail : penaliterasi@umj.ac.id

memberikan jiwa ke dalamnya beserta jalan cerita di masa hidupnya.

Dalam novel Semua Ikan di Langit juga ditemukan tiga simbol yaitu simbol kebahagiaan yang digambarkan dengan cahaya atau bintang, simbol kesedihan yang digambarkan dengan turunnya hujan dan yang terkahir simbol kemarahan yang digambarkan dengan bencana alam yang terjadi di dunia.

\section{REFERENSI}

Baharudin. (2014). Konsep Ketuhanan

Sepanjang Sejarah Manusia. Al-

Adyan, 35-36..

Fajar Risman Gunawan, S. (2018).

SIMBOL DALAM KUMPULAN

PUISI SERIBU KEKUPU KARYA

SURACHMAN RADEA MAMAN

. Lingua Franca, 102-103.

Febri Nur Indahsari, S. d. (2013). Konsep

Nrima pada Novel Pengakuan

Pariyem: Kajian Semiotika Umberto

Eco. Jurnal Sastra Indonesia, 2-4.

Patriansyah, M. (2014). Analisis Semiotika

Charles Sanders Peirce Karya

Patung Rajudin Berjudul Manyeso

Diri. Ekspresi Seni, 242.

Poedjawijatna. (1986). Etika Filsafat

Tingkah Laku. Jakarta: PT. Bina

Aksara.

Ratna, N. K. (2004). Teori, Metode, dan

Teknik Penelitian Sastra.

Yogyakarta: Pustaka Pelajar.
Sobur, A. (2006). Semiotika Komunikasi. Bandung: Remaja rosdakarya.

Zar, S. (2004). FILSAFAT ISLAM Filosof dan Filsafatnya. Jakarta: PT.

Rajagrafnda Persada. 